\title{
The occurrence of Upper Jurassic limestones in Cracow area and examples of their usage in the city architecture
}

\author{
Występowanie wapieni górnej jury na terenie Krakowa \\ i przykłady ich wykorzystania $\mathrm{w}$ architekturze miasta
}

\section{Agnieszka Majer-Durman}

AGH University of Science and Technology, Faculty of Geology, Geophysics and Environment Protection, al. Mickiewicza 30, 30-059 Kraków, Poland

e-mail:amdurman@geolog.geol.agh.edu.pl
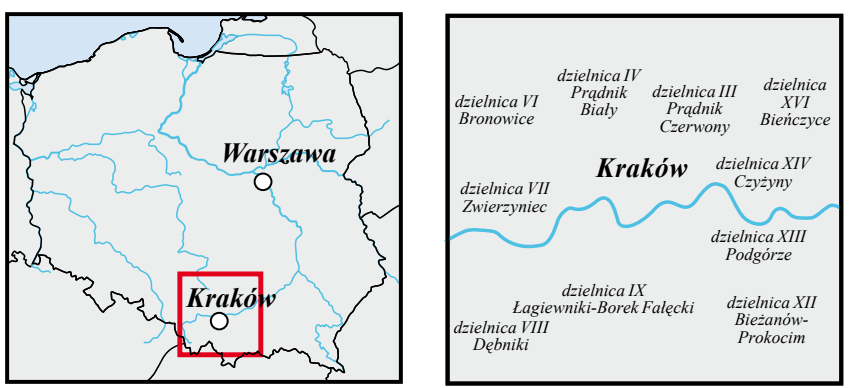

Abstract: This article presents basic information on the occurrence of Upper Jurassic limestones in the Cracow area and their exploitation in the past as well as providing some examples of their usage in the architecture of the city. Also, a proposal is presented of geotouristic trail to the Upper Jurrasic limestone a quarries located within the city area and through the most interesting architectural objects in Cracow, in which these limestones were used.

Key words: Cracow, architecture, Upper Jurassic limestones

Treść: Artykut przedstawia podstawowe informacje na temat występowania wapieni górnojurajskich na terenie Krakowa, miejsca ich eksploatacji w przeszłości oraz podaje przykłady wykorzystania $w$ architekturze miasta. Omówiono reprezentatywne sposoby ich architektonicznego zastosowania. Artykut zawiera propozycje trasy geoturystycznej po kamieniołomach wapieni jurajskich na terenie miasta i po najciekawszych obiektach architektonicznych Krakowa, w których te wapienie zostaty wykorzystane.

Stowa kluczowe: Kraków, architektura, wapienie górnej jury
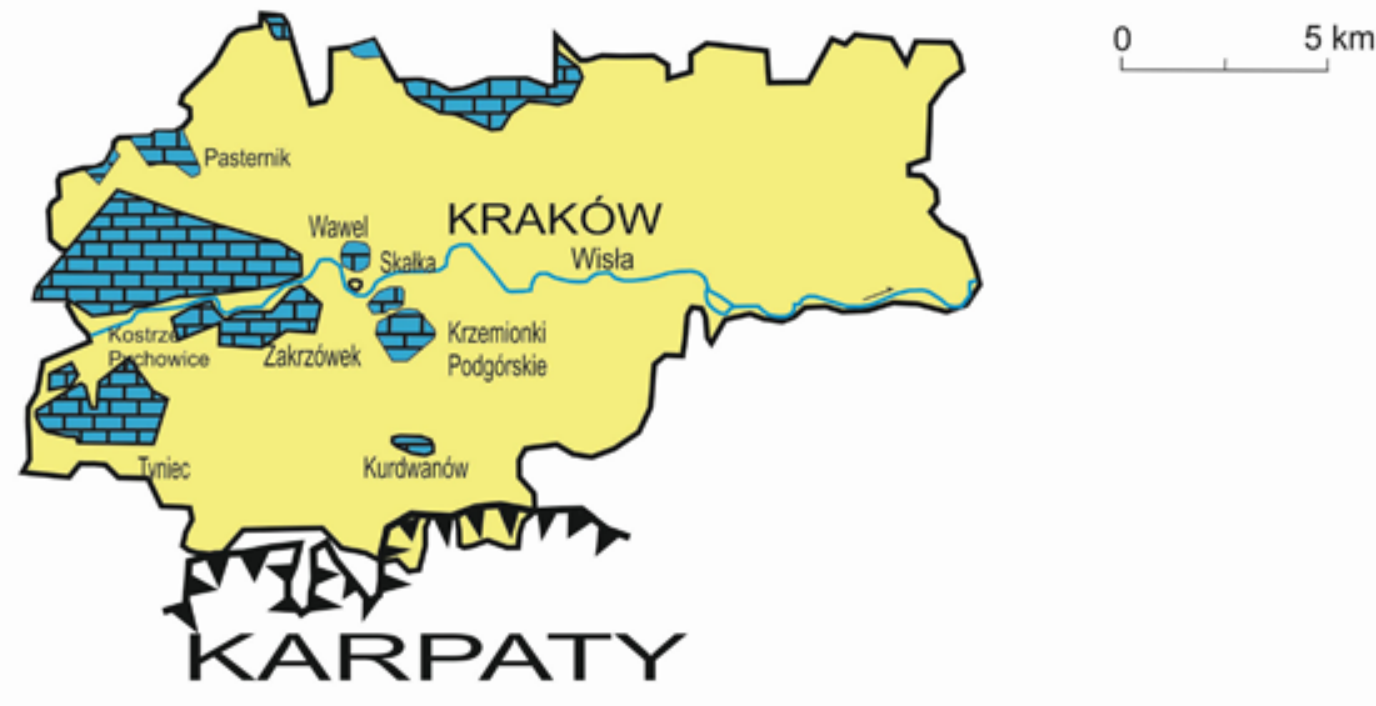

Miocene (miocen)

Mesozoic

(utwory mezozoiczne)

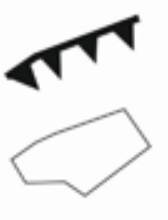

Carpathian overthrust margin (granica nasunięcia Karpat)

administrative boundary of the city (granica administracyjna miasta)

The Vistula river (rzeka Wisła)

Fig. 1. Geological sketch map of Cracow (after Rutkowski et al., 1998, changed) • Szkic geologiczny Krakowa (wg Rutkowskiego $i$ in., 1998, zmieniony) 


\section{Introduction}

Over seven million people visit Cracow each year. Tourists from various parts of the world admire numerous secular and sacral monuments of the historical capital seat of the Polish Kingdom. However, the diversity and beauty of the architectural monuments causes that only a fraction of visitors pay attention to the rocks from which the historical buildings were constructed. When starting the adventure with culture and monuments, it is worthnoting to recognize both the examples of exploitation and application of the most common construction stone in the Cracow region - the Upper Jurassic limestone.

\section{Geology}

The Cracow region belongs to the Silesia-Cracow Monocline, which extends east-west between the Upper Oder and the Upper Vistula rivers and north-south between the Warta and the Pilica rivers sources (Gradziński, 1972). Within the monocline limits we can recognize the older structural stage built of Paleozoic rocks including the Carboniferous, which were folded during the Variscan orogeny and the younger one, composed of Permian, Triassic, Jurrasic and Cretaceous

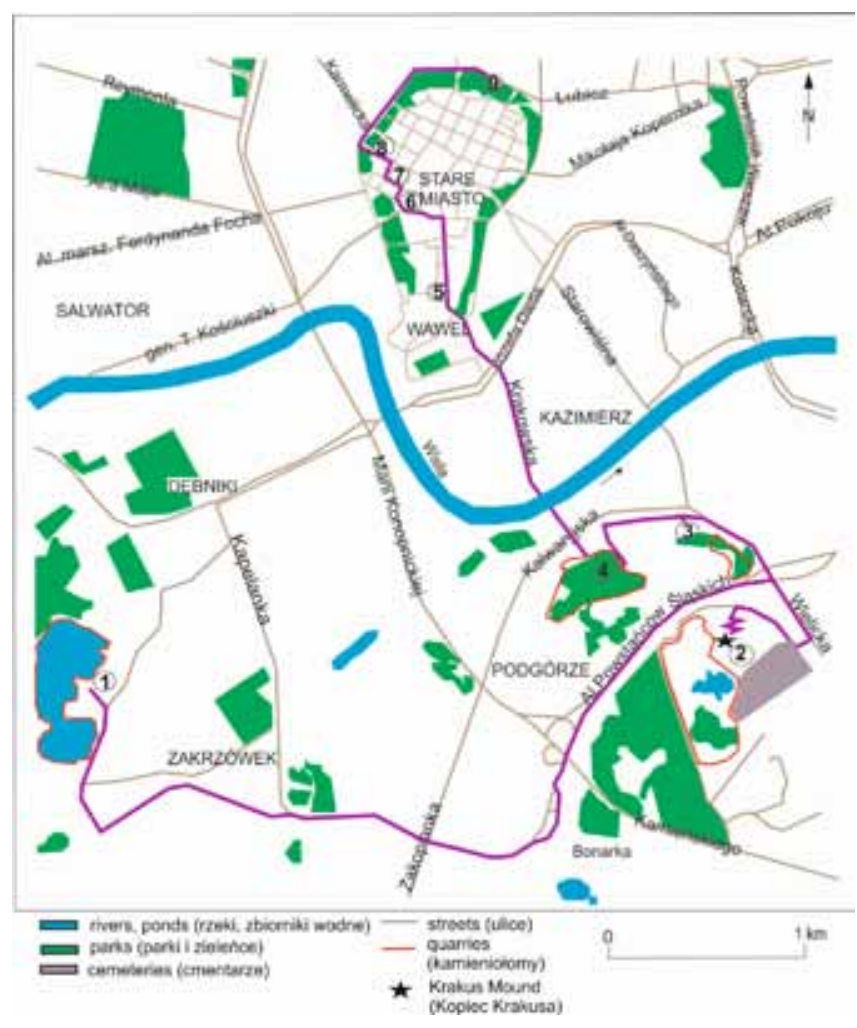

Fig. 2. Proposal of the geotouristic trail (purple line): 1 - Zakrzówek quarry, 2 - Liban quarry, 3 - St. Benedictine quarry, 4 Twardowski's School quarry, 5 - fragment of pavement by the St. Idzi Church, 6 - Franciscan Church, 7 - Collegium Maius, 8 - St. Anne Collegiate, 9 - Florian Gate • Propozycja trasy geoturystycznej (fioletowa linia): 1 - kamieniołom Zakrzówek, 2 - kamieniołom Liban, 3 - kamieniołom Pod św. Benedyktem, 4 - kamieniołom Szkoła Twardowskiego, 5 - fragment nawierzchni przy kościele św. Idziego, 6 - kościół oo. Franciszkanów, 7 - Collegium Maius, 8 - kolegiata św. Anny, 9 - Brama Floriańska formations (Gradziński, 1972). These two stages are separated by erosional angular unconformity. During the Alpine orogeny the northward-directed pressure from the overthrusting Carpathian nappes resulted in the breaking of the Silesia-Cracow Monocline into the system of large and small horsts and grabens. The most important horsts within the Cracow City area are: Wawel, Skałka, Pasternik, Kurdwanów, Krzemionki Podgórskie, Zakrzówek, Tyniec and Kostrze-Pychowice (Fig. 1).

The Upper Jurassic Oxfordian and Kimmeridgian limestones complex in the Cracow region is about 250 meters thick (Matyszkiewicz, 2001). Limestones were deposited in the shallow, epicontinental sea where siliceous and calcareous sponges, and blue-green algae (cyanobacterias) were rock-forming organisms (Matyszkiewicz, 1993). Thanks to the living activity of these organisms, bioherms and spongealgal reefs were formed and transformed during diagenesis into massive limestones facies represented by white or cream, hard, compact rocks devoid of bedding. The destruction of reefs related to the lowering of the wave base gave rise to the bedded limestones facies deposited between the bioherms and reefs. The bedded facies comprise of white and grey limestones with numerous, dark-brown or bluish-green flints (Rajchel, 1970). Sharp boundaries with enclosing rocks are visible in flints which occur in bedded limestones (Świerczewska, 1989). The third facies of the Upper Jurrasic carbonates are whitish platy limestones precipitated chemically in an open-sea environment. These are characterized by an abundance of fossils, especially Perisphinctes ammonites shell casts (Gradziński, 1972). These three lithofacies built the Upper Jurassic limestones complex of the Cracow surroundings.

\section{Geotouristic routes}

Within the Cracow city area we can encounter Upper Jurassic limestones in natural exposures, in quarries and in architectural elements of buildings. For more than one thousand years these rocks have been commonly applied as construction stones for town walls system, monasteries, secular buildings as well as monuments and gravestones (Rajchel, 2008). The proposed trail leads through the most interesting Upper Jurassic limestone quarries located within the city. It is about 12 kilometers long (Fig. 2) and the sighseeing takes approximately 3 hours. The difficulty level is low. The trail is intended for individual tourists as well as for groups of ten to twenty people, who can walk or take public transport or private cars. The trailhead and the trail end are located close to the public transport stops.

The first site where we can observe the Upper Jurrasic limestones is the Zakrzówek quarry, at the Wyłom Street (a cross street of the General Stefan Grot-Rowecki Street) (Fig. 2, point 1). Today, this is a huge, abandoned quarry, consisting of several excavations where walls are up to 40 meters high. Limestone quarrying started in 1906 and ceased in 1991. In the quarry walls bedded Upper Jurrasic limestones facies can be found (Fig. 3), which includes four lithologic types: micritic, lumpy, chalky and granular the 
limestones with dolomites (Krajewski, 2001). The thickness of limestone beds varies from 0.5 to 2.0 meters. Bedding is underlined by flint levels (Dżułyński, 1953). The lowermost part of the sequence comprises of flat-lying, hard, compacted, micritic limestones with flints. Above, within the bedded limestones the lenses of chalky limestones occur in thickness reaching several meters. This is the only exposure of this limestone type in the Cracow region. It is characterized by the occurrence of numerous benthic fauna (sponges, brachiopods). Up the sequence, there appear lumpy limestones, with lumps of 10-25 cm in diameter (Krajewski, 2001). Massive limestones are also present there, which are the most resistant Upper Jurassic limestone facies to weathering and erosion. In the whole limestones formations we can find traces of karst processes in the form of small sinks filled with residual deposits and vegetation. After the closure of limestone excavations in 1991 the open pit was left unprotected and it was gradually flooded by groundwaters. At present, this is a deep basin open to the public for diving. The Zakrzówek quarry is an example of adaptation of an old mining site.

The next site of the trail requires the travel by bus No. 178, from the Powstańców Śląskich Street to the Wielicka Street. We leave the bus and walk eastward, along this street after about 400 meters we reach the Podgórze graveyard. Continuing further along the Pod Kopcem Street, we reach the Krakus mound. It is a perfect site from which visitors can admire the panorama of Cracow. Not far from the mound, to the northeast there is an another object of interest on the trail - the Liban quarry (Fig. 2, point 2). It was founded by Bernard Liban in 1873 , as a source of lime for the Liban \& Ehrenpreiss company. It covers an area of 18 hectares. This is a vast excavation with several levels and steep, almost 30 meter high walls. Here, the Upper Jurassic bedded limestones appear (Fig. 4). Limestone beds show thicknesses from several dozen of centimeters to several meters. Within the beds as well as along the interbedding planes we can observe numerous flint nodules, about $10-15 \mathrm{~cm}$ in diameter. In the western wall of the quarry fossil karst sinkholes are visible, filled with clayey karstic deposits and limestone blocks containing numerous flint fragments (Rajchel, 1970).

After a visit to the Liban quarry we come back with the Pod Kopcem avenue to the Wielicka street and turn west, along Limanowski Street towards Rękawka Street from which we enter the St. Benedict quarry (Fig. 2, point 3). This is one of the oldest quarries in Cracow area, operating since Medieval times. According to documents it has been the property of the city since 1375 (Górecki, Sermet, 2010). The area of the excavation is 0.85 ha, and walls are up to $20 \mathrm{me}-$ ters high (Szczepańska, 2005). The main facies is the massive limestone in which well-developed joint systems are visible (Szczepańska, 2005). Today, on account of overgrowing shrubs and trees, the quarry walls are barely visible and the excavation plays only a role of recreational site for residents.

Going further west, along Rękawka and Jan Zamoyski Streets, we reach Parkowa Street. The second oldest quarries appears there, the so-called "Twardowski School" (Fig. 2, point 4), in which Upper Jurrasic limestones were excavated for the purpose of city construction. The quarry had

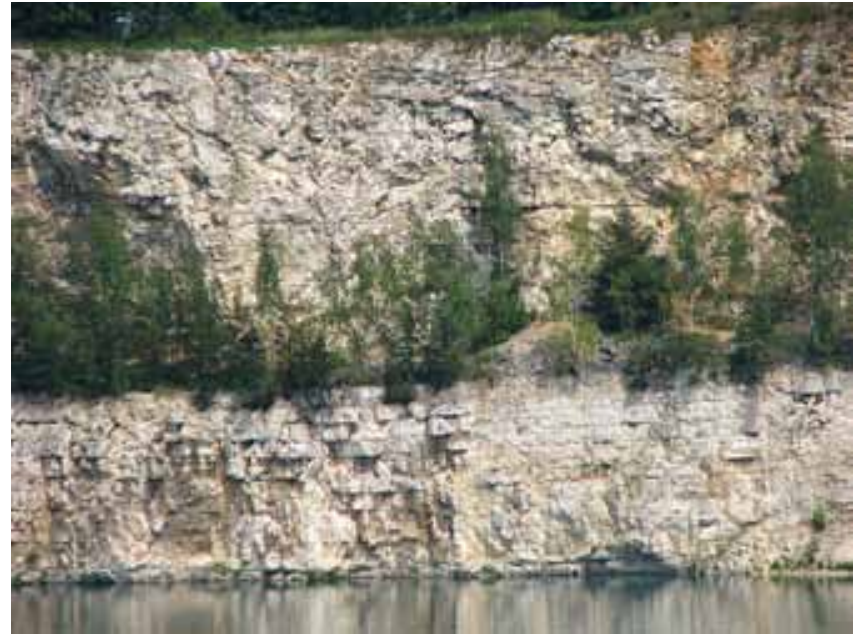

Fig. 3. Bedded limestones outcrop in the Zakrzówek quarry, phot. A. Majer-Durman • Odsłonięcie wapieni uławiconych w kamieniołomie Zakrzówek, fot. A. Majer-Durman

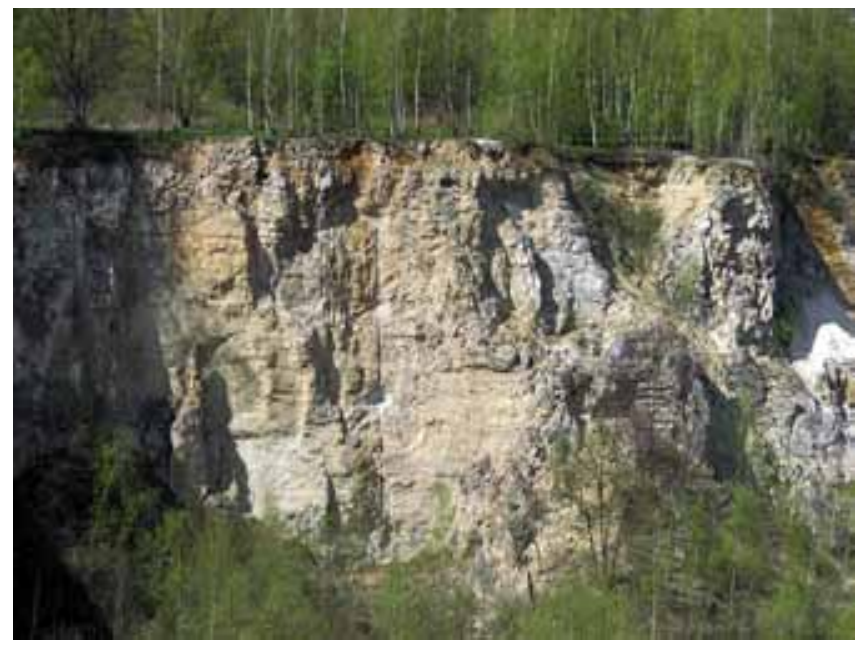

Fig. 4. Upper Jurassic bedded limestones outcrop in the Liban quarry, phot. A. Majer-Durman • Odsłonięcie wapieni uławiconych górnej jury w kamieniołomie Liban, fot. A. Majer-Durman

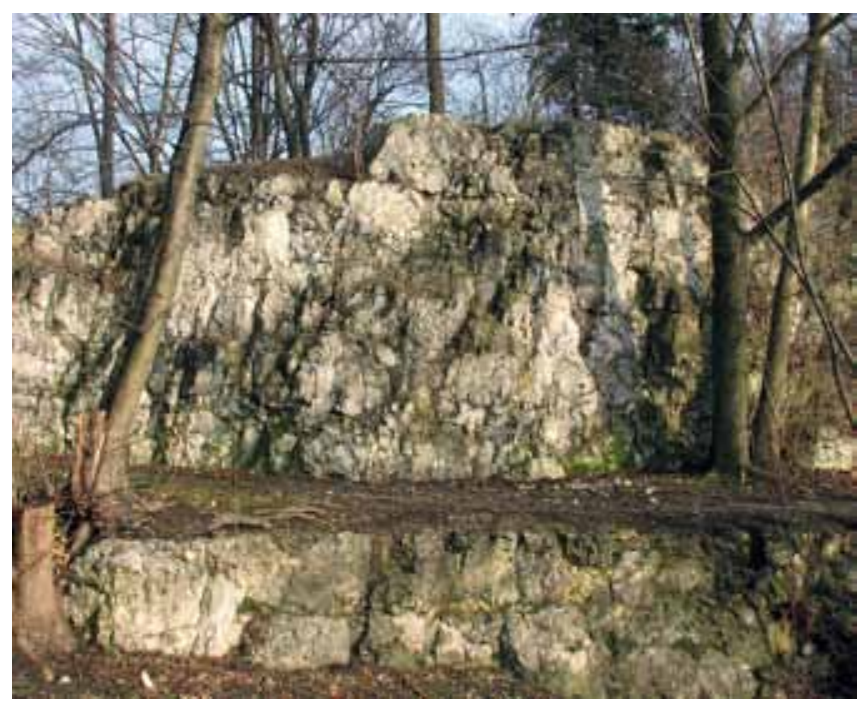

Fig. 5. Upper Jurassic limestones outcrop in the Bednarski Park, phot. A. Majer-Durman • Odsłonięcie wapieni górnojurajskich w Parku im. W. Bednarskiego, fot. A. Majer-Durman 


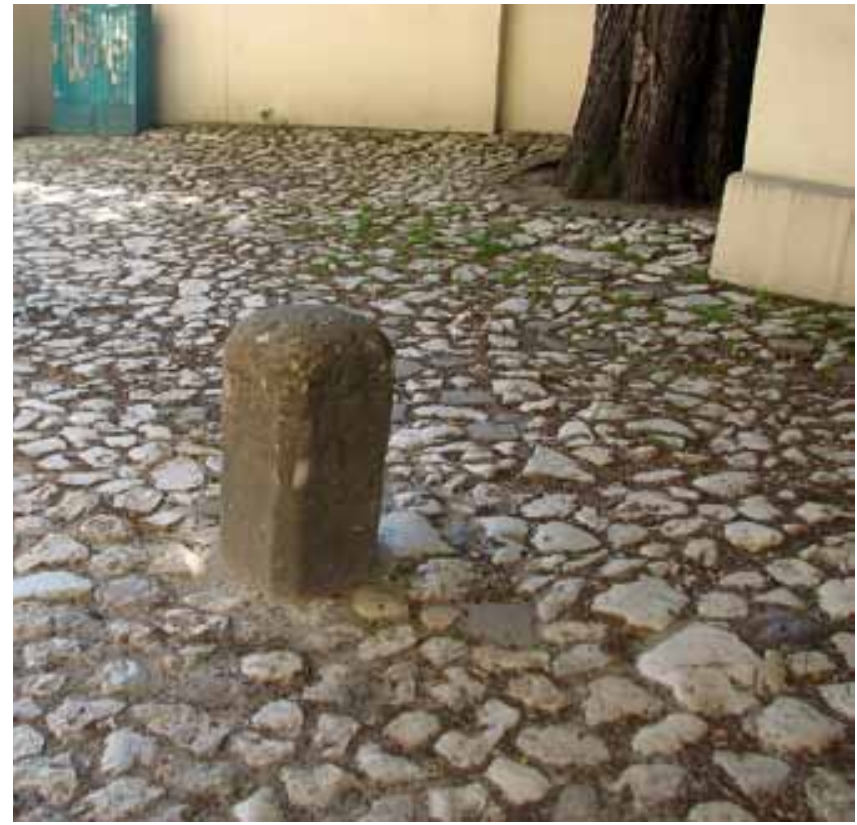

Fig. 6. Fragment of the road pavement made of cobblestones by the St. Idzi Church, phot. A. Majer-Durman • Fragment nawierzchni utworzony z tzw. „kocich łbów” przy kościele św. Idziego, fot. A. Majer-Durman been active until 1884 (Górecki, Sermet, 2010). According to legend, Master Twardowski improved his artistry there and collected innumerable treasures (Źółciak, Żółciak, 2007). This ellipsoidal excavation covers the area of 3.6 ha and walss are from 3 to 16 meters high (Fig. 5) (Górecki, Sermet, 2010). In the walls thick-bedded limestones with flints appear. In 1896 the abandoned quarry was transformed by Wojciech Bednarski to a public park, nowadays called "The Bednarski Park" (Żółciak, Żółciak, 2007). This is another example of successful reclamation of an old mine working.

After recognition of the old, Upper Jurassic limestones quarries located in the former city outskirts, we are now going to the city centre. Leaving the Park and heading to the west, after about 100 meters, we reach Kalwaryjska Street. At the stop "Korona", we take tram No. 3, 6, 8 or 10 and, after 10 minutes, we approach the Wawel Hill at the exit of Grodzka Street. At the intersection of Grodzka and the St Idzi streets we examine the first site where Jurrasic limestones were used in the city architecture (Fig. 2, point 5). Around St. Idzi church there appear fragments of the old road with well-preserved cobblestones. This pavement was made of irregular limestone lumps from several to several dozens of centimeters across. Their oval shapes were an

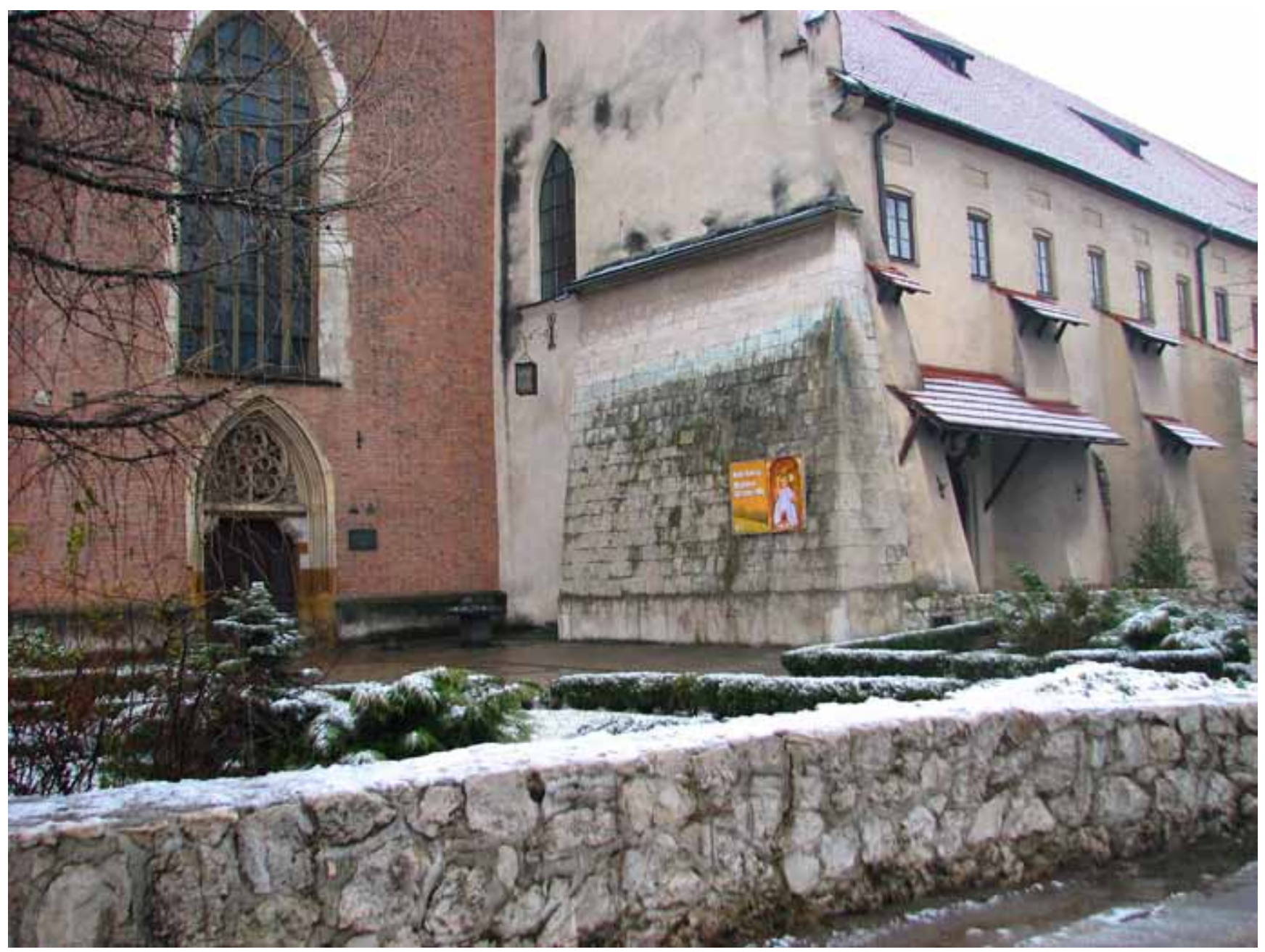

Fig. 7. Jurassic limestone escarpment by the Franciscan Church, phot. A. Majer-Durman • Skarpa z wapienia jurajskiego przy kościele oo. Franciszkanów, fot. A. Majer-Durman 
effect of repeated rearrangement and long-lasting usage (Rajchel, 2009). This site enables us to imagine how old streets in historical Cracow looked like in the past (Fig. 6).

After about a 500 meters walk along Grodzka Street we turn left to Franciszkańska Street, where a Franciscan church and monastery are located (Fig. 2, point 6). This is one of the first churches in Poland built of bricks but splendid buttresses of this church are built of Upper Jurrasic limestone blocks, so-called grand appareil. Within the Old City area we can observe numerous buttresses (banks) made of this rock. An excellent example is a buttress of the building of the Saint Jacob lecture theatre, close to the main entrance to the Franciscan church (Fig. 7). Another beautiful example is a buttress of the Collegium Maius building (Fig. 8) at the corner of Jagiellońska and St. Anna streets (Rajchel, 2004), which is the next point on our trail (Fig. 2, point 7). We can reach this point walking about 120 meters along the park. A fragment of the elevation of this building is worth noting - it is made of limestone lumps, the so-called opus incertum (Fig. 8), well-visible in the wall from the side of Jagiellońska Street. In limestone blocks we can find numerous fossils, for example ammonites (Fig. 9). At this site we can pay a visit to the Collegium Maius building, which has been the seat of the Jagiellonian University and the museum since 1400 AD. In the courtyard of the Collegium Maius we can admire columns made of Upper Jurassic bedded limestones with protruding flint nodules, up to $15 \mathrm{~cm}$ in diameter (Fig. 10).

Leaving Collegium Maius we walk further, towards St. Anns collegiate, which is situated on the street of the same name (Fig. 2, point 8). This church ranks among the most beautiful Baroque monuments in Poland. The present church is the third building standing at this site. The foundations of the contemporary collegiate were laid down in 1689 (Rożek, 1993). In the church the Saint Jan Kanty chapel is spectacular, with 7.5 meter-tall columns made of the so-called "blessed Salomea marble" (Fig. 11). This "marble" is the Upper Jurassic biohermal sponge limestone, belonging to the massive limestone facies, excavated in the past in the Ojców surroundings (Holcer, Krajewski, 2001).

The raw limestone blocks were readily used in the construction of the city fortifications. The spectacular example is the St. Florian Gate (Fig. 2, point 9) and the Ciesielska and the Pasamonik towers - the relics of former city walls (Rajchel, 2004). To get to the Floriańska Gate, we must walk Dunajewski and Basztowa streets. The first notes about the St. Florian Gate come from 1307. At that time the stony pedestal and the walls were raised, whereas the dome was built in 1694, because the gate was damaged during the Swedish invasion. The Gate is about 34 meters high (Michalec, 2005). Its walls are built from raw, broken Upper Jurrasic limestone blocks.

\section{The aim of the geotouristic trail}

Cracow is famous for its variety of architectural monuments of different styles. The proposed geotouristic trail shows the city from a different perspective. It brings attention to the Upper Jurassic limestones, one of construction stones typical of Old Cracow architecture, by showing the limestone exploitation sites where the origin of this rock can be examined. The aim of the trail is also to become familiar with the geological structure of the city area.

In order to examine the knowledge of the sites of occurrence and architectural usage of the Upper Jurassic limestone in Cracow, a public pool has been carried out using 100 random respondents of various age. The questionnaire included several simple questions. The questionnaire consisted of the following questions:

- "Do you think that quarries exist within the area of Cracow?"

- "If you answered yes, please give their names or locations." - "Do you know what rock material was often used in buildings in Cracow?"

- "If you answered yes, please give the name of this rock material."

The aim of these questions was also to gather opinions of the respondents about the sense of geotouristic trail organization.

Another question was: "Do you think that organization of a geotouristic trail showing the sites of natural occurrence of limestones used in buildings in Cracow would be a successful extension of the touristic offer?"

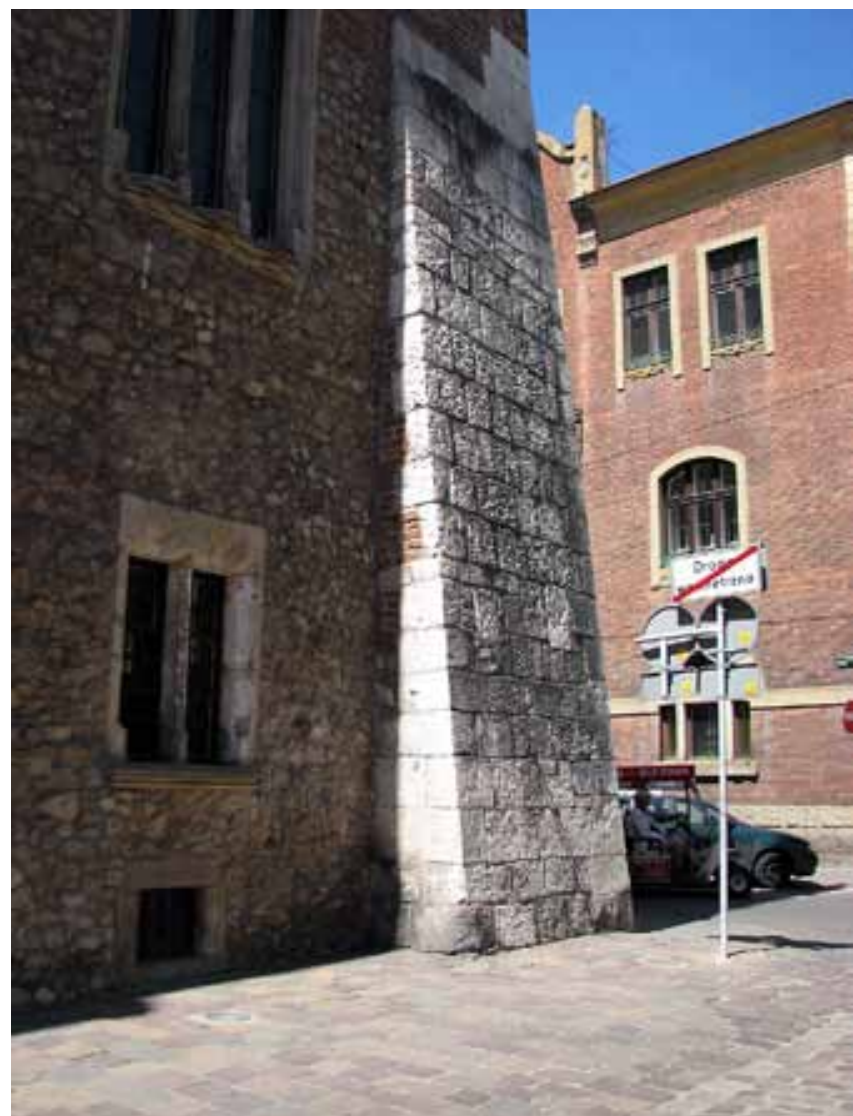

Fig. 8. Collegium Maius building with escarpment made of the Upper Jurassic grand appareil blocks, as well as fragments of the opus incertum wall made of the same material, phot. A. Majer-Durman - Budynek Collegium Maius na rogu ulic Jagiellońskiej i św. Anny. Widoczna skarpa $\mathrm{z}$ bloków grand appareil $\mathrm{z}$ wapienia górnojurajskiego oraz fragment muru opus incertum $\mathrm{z}$ tego surowca, fot. A. Majer-Durman 


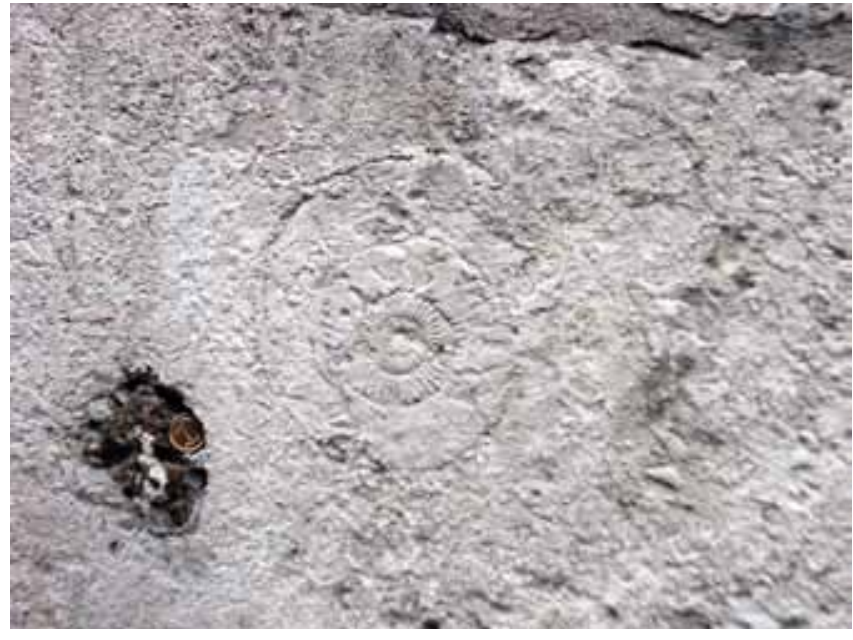

Fig. 9. Ammonite in the Upper Jurrasic limestone block in Collegium Maius walls, phot. A. Majer-Durman • Ośródka amonita w bloku górnojurajskiego wapienia murów Collegium, fot. A. Majer-Durman

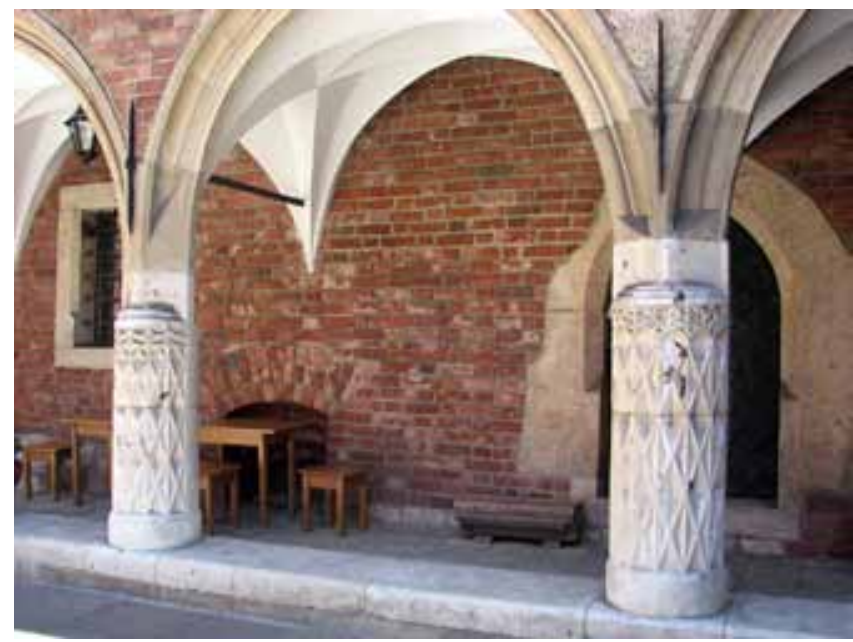

Fig. 10. Columns made of massive limestone with flints in the courtyard of the Collegium Maius, phot. A. Majer-Durman - Kolumny wykonane $\mathrm{z}$ wapienia skalistego $\mathrm{z}$ krzemieniami na dziedzińcu Collegium Maius, fot. A. Majer-Durman

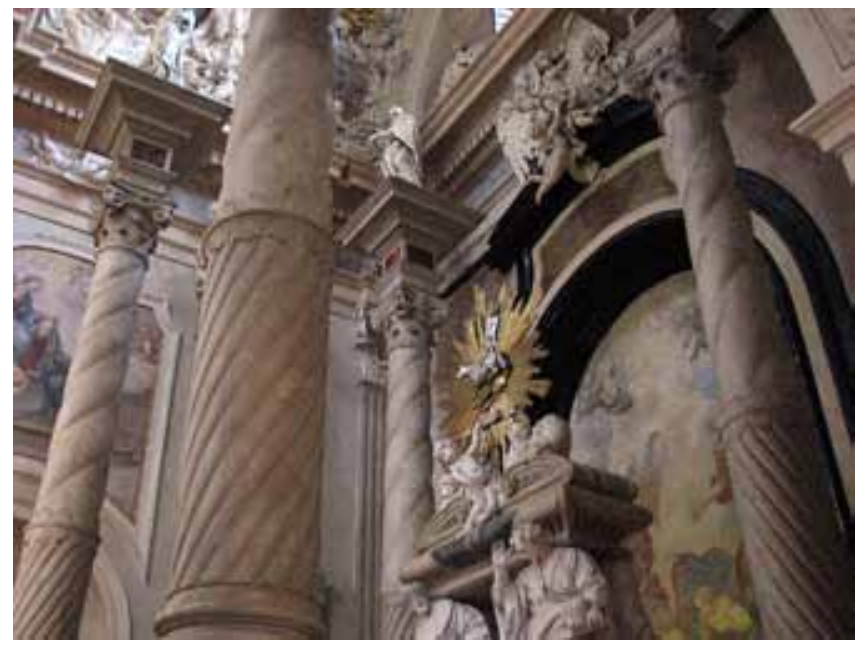

Fig. 11. Columns made of the "blessed Salomea's marble" in the St. Anne Collegiate in Cracow, phot. A. Majer-Durman • Kolumny z „marmuru bł. Salomei” w kolegiacie św. Anny w Krakowie, fot. A. Majer-Durman
The answers were analyzed considering respondents education and age, the latter divided into three age groups: 18-30, 31-55 and over 56 years old. According to the answers, $58 \%$ of respondents are aware of quarry occurrence within the Cracow area, in particular age groups: $44 \%, 69 \%$ and $78 \%$, respectively. In the group $18-30$ years old, the knowledge of this subject is poorest.

Definitely, it was more difficult for respondents to indicate the names and locations of existing quarries. Precisely, $54 \%$ of them could not indicate any excavation, in which $64 \%$ in $18-30$ years group, $53 \%$ in $31-55$ years group and only $28 \%$ in over 56 years group old. One quarry name was given by $31 \%$ of the respondents, and only $9 \%$ of respondents knew the names of two quarries. The best knowledge of Cracow's quarries was indicated by respondents over 56 years old (50\% gave one name, $17 \%$ gave two names). In the group of the youngest respondents only $4 \%$ could point out more than two names of limestone quarries located within the city.

The level of knowledge of rocks used in the Cracow architecture was also measured. Hence, $50 \%$ of respondents knew which rock was used in constructions, out of which $62 \%$ in the youngest group and $72 \%$ in the oldest group. In the middle-age group more than $66 \%$ of respondents knew nothing about this subject. Among rocks mentioned as building stones the respondents indicated: limestones (42\%), sandstones and granites (13\%), and marbles (3\%).

The survey revealed that the knowledge of rocks used in buildings as well as the sites of their exploitation is unsatisfactory. Maybe, that is the reason why $90 \%$ of respondents declared the need of organizing the geotouristic trail which would combine these two aspects. In particular age groups $90 \%, 84 \%$ and $100 \%$, respectively, supported the organization of the trail. Taking into account the education level of respondents, those who revealed vocational secondary education showed the broadest knowledge of city quarries $(89 \%)$, whereas those with secondary and higher education demonstrated definitely lower level of knowledge (67 and $66 \%$, respectively). Considering the building stones used in Cracow, $67 \%$ of respondents with secondary education and $56 \%$ of those with vocational secondary education revealed better knowledge of the topic. Finally, $100 \%$ of respondets with secondary education and $94 \%$ of those with higer education supported the idea of a geotourist trail.

\section{Summary}

For an average person tourism is associated with nature observation and/or visiting picturesque landscape outlooks and experiencing esthetic impressions. At present, the cognitive function of urbanized areas is narrowed to the visits and recognition of historical monuments. Visitors rarely pay attention to the rocks used in the construction of particular architectural elements. The survey revealed that tourists do not have knowledge of the origin of the rocks used in the construction of monuments and their knowledge of exploitation sites of building stones is even lower. There is no such information in advertising materials and in tourist guides. 


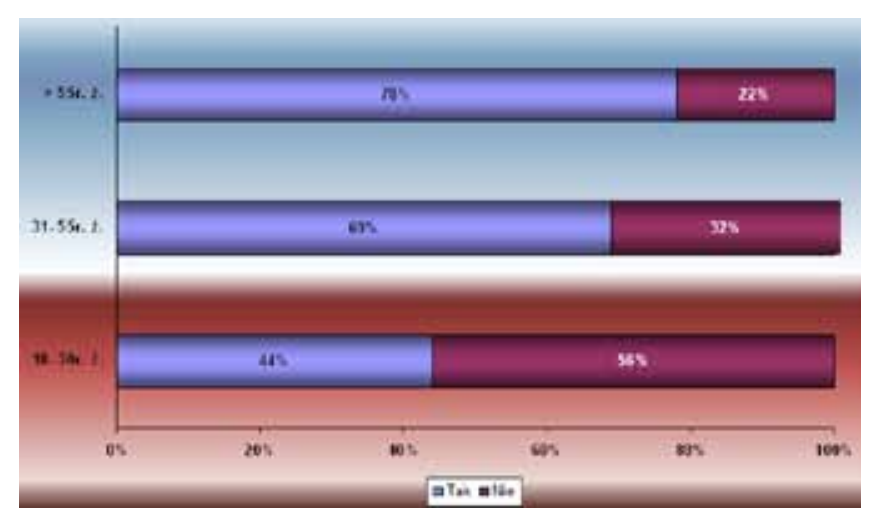

The proposed geotouristic trail brings attention to this problem and creates a new offer for those who are interested in this topic, at the same time rising their knowledge of visited and admired architectural and historical objects. $\square$

Fig. 12. Percentage of answers to the question: Do you think that quarries exist within the area of Cracow? $\bullet$ Procentowy udział odpowiedzi na pytanie: „Czy Pana/pani zdaniem na terenie Krakowa występują kamieniołomy?”

\section{Streszczenie \\ Występowanie wapieni górnej jury na terenie Krakowa i przykłady ich wykorzystania w architekturze miasta}

\section{Agnieszka Majer-Durman}

\section{Wstęp}

Ponad siedem milionów osób rocznie odwiedza Kraków. Turyści $\mathrm{z}$ różnych stron świata podziwiają liczne zabytki świeckie i sakralne miasta królów Polski. W całym przepychu różnorodności niewiele osób zwraca uwagę na materiał skalny, z którego zbudowane są podziwiane od wieków budowle. Rozpoczynając przygodę z kulturą i zabytkami, warto poznać miejsca występowania oraz wykorzystania w architekturze wapienia górnej jury, jednego z najpowszechniej eksploatowanych surowców skalnych okolic Krakowa.

\section{Budowa geologiczna}

Obszar Krakowa znajduje się na terenie monokliny śląsko-krakowskiej, która rozciąga się między górną Odrą i górną Wisłą oraz źródłami Warty i Pilicy (Gradziński, 1972). W jej obrębie wyróżniamy starsze piętro strukturalne, zbudowane z utworów paleozoicznych, do karbonu włącznie, sfałdowanych w orogenezie hercyńskiej i młodsze, złożone z utworów permu, triasu, jury i kredy (Gradziński, 1972). Piętra te rozdzielone są niezgodnością erozyjno-kątową. W trakcie orogenezy alpejskiej na skutek nacisku nasuwających się od południa Karpat krawędź monokliny śląsko-krakowskiej uległa rozpadowi na szereg większych i mniejszych zrębów i rowów tektonicznych. Najważniejszymi zrębami na terenie Krakowa są: zrąb Wawelu, Skałki, Pasternika, Kurdwanowa, Krzemionek Podgórskich, Zakrzówka, Tyńca i Kostrza-Pychowic (Fig. 1).

Kompleks wapieni górnojurajskich oksfordu i kimerydu w rejonie Krakowa osiąga około 250 metrów miąższości (Matyszkiewicz, 2001). Powstały one w płytkim morzu epikontynentalnym, gdzie organizmami skałotwórczymi były gąbki krzemionkowe i wapienne oraz sinice (cyanobakterie) (Matyszkiewicz, 1993). Dzięki działalności życiowej tych organizmów tworzyły się biohermy i rafy gąbkowo-sinicowe. Utworzone $\mathrm{z}$ tych budowli wapienie facji skalistej, to skały zbite, twarde i nieuławicone, o barwie brudnobiałej na powierzchni zwietrzałej, na świeżym przełamie białej. W wyniku degradacji związanej z obniżeniem podstawy falowania, ulegały one niszczeniu, a $\mathrm{z}$ ich rozdrobnionego materiału, na przedpolu powstawały osady tworzące tzw. wapienie uławicone. Są to skały barwy białoszarej, w których występują konkrecje krzemionkowe barwy ciemnobrunatnej lub niebieskawoszarej (Rajchel, 1970a). W występujących w horyzontach śródwarstwowych krzemieniach widoczne są ostre granice z otaczającą skałą (Świerczewska, 1989). Trzecią odmianę facjalną wapienia górnojurajskiego stanowią osady będące produktem sedymentacji w strefie otwartego morza, głównie na drodze chemicznego wytrącania $\mathrm{CaCO}_{3}$ $\mathrm{z}$ wody morskiej. Są to jasne wapienie płytowe. Charakteryzują się one znaczną ilością skamieniałości, zwłaszcza odlewami muszli amonitów z rodzaju Perisphinctes (Gradziński, 1972). Te trzy odmiany litologiczne tworzą kompleks wapieni górnojurajskich okolic Krakowa.

\section{Trasa geoturystyczna}

Na terenie Krakowa można obserwować wapienie górnej jury zarówno w miejscach ich naturalnych odsłonięć, kamieniołomach, a także w elementach architektonicznych budowli krakowskich. Od przeszło 1000 lat stanowiły one powszechnie stosowany materiał skalny na potrzeby najszerzej rozumianej architektury miasta. W przeszłości wapienie jurajskie były przedmiotem eksploatacji przede wszystkim na potrzeby budownictwa. Z surowca tego wznoszono mury obronne, klasztory, budowle świeckie oraz pomniki i nagrobki (Rajchel, 2008). Proponowana trasa prowadzi przez najciekawsze kamieniołomy wapieni górnojurajskich znajdujących się w obrębie miasta. Trasa (Fig. 2) liczy około 12 kilometrów, a na jej przejście potrzeba około 3 godzin. Charakteryzuje się ona małą skalą trudności. Trasę mogą zwiedzać turyści indywidualni oraz grupy kilkunastoosobowe. Można ją pokonać zarówno pieszo, jak i korzystać z komunikacji miejskiej lub własnego środka transportu. Początkowy, jak i końcowy punkt trasy znajduje się w pobliżu przystanków komunikacji miejskiej.

Pierwszym punktem na geoturystycznej trasie, w którym możemy zaobserwować wapienie górnojurajskie, jest kamieniołom Zakrzówek, położony przy ulicy Wyłom (przecznica ul. gen. Stefana Grota-Roweckiego) (Fig. 2, pkt. 1). Jest to dzisiaj ogromny, rozległy kamieniołom składający się z kilku wyrobisk, których ściany dochodzą do 40 metrów wysokości. Eksploatację na tym terenie prowadzono od 1906 roku. 
W kamieniołomie występują górnojurajskie wapienie uławicone (Fig. 3), wśród których wyróżniamy cztery typy: mikrytowe, gruzłowate, kredowate oraz ziarniste $\mathrm{z}$ dolomitami (Krajewski, 2001). Grubość ławic wapieni wynosi tu od 0,5 do 2 metrów. Uławicenie podkreślone jest poziomami konkrecji krzemionkowych (Dżułyński, 1953). Najniżej w profilu zalegają poziomo, twarde, zbite wapienie mikrytowe, w których występują konkrecje i płaskury krzemionkowe. Wyżej położone są wapienie kredowate w formie soczewek, wśród wapieni uławiconych, których miąższość dochodzi do kilkunastu metrów. Jest to jedyne w rejonie krakowskim odsłonięcie tego typu wapieni. Charakteryzują się występowaniem licznej fauny bentonicznej (gąbki, ramienionogi). Wyżej w profilu są wapienie gruzłowate, których gruzły osiągają średnice od 10 do $25 \mathrm{~cm}$ (Krajewski, 2001). Występują tu także wapienie skaliste, które są najbardziej odporną na wietrzenie i erozję facją wapienia górnojurajskiego. W występujących tu skałach wapiennych widoczne są ślady zachodzących procesów krasowych, w postaci niewielkich lejów wypełnionych zwietrzeliną i roślinnością. Zaprzestanie wydobycia surowca skalnego w 1991 roku spowodowało stopniowe zalanie wyrobiska wodą gruntową. Obecnie powstały w kamieniołomie akwen jest udostępniany do celów nurkowania. Zakrzówek jest więc przykładem możliwości wykorzystania i zagospodarowania dawnego wyrobiska poeksploatacyjnego.

Do kolejnego punktu trasy przejeżdżamy autobusem nr 178 na przystanek przy ulicy Powstańców Śląskich, z którego skręcamy w ulicę Wielicką. Kierując się ku wschodowi wzdłuż tej ulicy, po około 400 metrach dochodzimy do cmentarza Podgórskiego. Idąc dalej wzdłuż alei Pod Kopcem dochodzimy do kopca Krakusa, skąd rozpościera się wspaniała panorama miasta. Niedaleko kopca w kierunku północnowschodnim znajduje się kolejny obiekt na proponowanej trasie - kamieniołom Liban (Fig. 2, pkt. 2). Założony został przez Bernarda Libana w 1873 roku jako wapiennik spółki Liban \& Ehrenpreis. Zajmuje powierzchnię 18 ha. Jest to rozległe wyrobisko o kilku poziomach i stromych, wysokich prawie na 30 metrów, ścianach. Odsłaniają się tutaj górnojurajskie wapienie uławicone (Fig. 4), których ławice osiągają miąższość od kilkudziesięciu centymetrów do kilku metrów. W obrębie ławic oraz $\mathrm{w}$ fugach międzyławicowych obserwuje się liczne buły krzemieni o średnicy ok. 10-15 cm. W zachodniej ścianie kamieniołomu widoczne są kopalne studnie krasowe, wypełnione osadami ilastymi oraz blokami wapienia zawierającymi liczne fragmenty krzemieni (Rajchel, 1970).

Wracamy aleją Pod Kopcem do ulicy Wielickiej. Następnie idąc w kierunku zachodnim ulicą Limanowskiego, skręcamy w ulicę Rękawka, przy której znajduje się kamieniołom Pod św. Benedyktem (Fig. 2, pkt. 3). To jeden z najstarszych, działających już w średniowieczu kamieniołomów. Został on zakupiony przez miasto w 1375 r. (Górecki, Sermet, 2010). Powierzchnia wyrobiska wynosi około 0,85 ha, a ściany dochodzą do 20 metrów wysokości (Szczepańska, 2005). Odsłaniają się tutaj głównie wapienie skaliste, w których widoczne są dobrze rozwinięte spękania ciosowe (Szczepańska, 2005). Dzisiaj ze względu na zarośnięcie krzewami i drzewami kamieniołom jest ledwo widoczny, spełnia jedynie rolę miejsca rekreacyjnego dla mieszkańców Krakowa.
Idąc dalej w kierunku zachodnim ulicą Rękawka i Jana Zamoyskiego dochodzimy do ulicy Parkowej. Znajduje się tutaj drugi z najstarszych kamieniołomów, tzw. Szkoła Twardowskiego (Fig. 2, pkt. 4), w którym eksploatowano górnojurajski materiał skalny na potrzeby miasta Krakowa. Kamieniołom funkcjonował do 1884 roku (Górecki, Sermet, 2010). Wedle legendy mistrz Twardowski doskonalił tu swój kunszt oraz gromadził nieprzebrane skarby (Żółciak, Żółciak, 2007). Jest to wyrobisko w kształcie niecki o powierzchni około 3,6 ha, którą otaczają ściany o wysokości od 3 do 16 metrów (Fig. 5) (Górecki, Sermet, 2010). Występują tu gruboławicowe wapienie z krzemieniami. W 1896 roku Wojciech Bednarski w miejscu nieczynnego kamieniołomu założył park miejski noszący obecnie nazwę Park Bednarskiego (Żółciak, Żółciak, 2007). Jest to kolejny przykład możliwości zrekultywowania dawnego wyrobiska poeksploatacyjnego.

Po zapoznaniu się z kamieniołami wapieni górnojurajskich na dawnych obrzeżach miasta udajemy się do centrum. Wychodząc z parku w kierunku zachodnim po około 100 metrach dochodzimy do ulicy Kalwaryjskiej. Z przystanku tramwajowego „Korona”, tramwajami linii: 3, 6, 8, 10, jedziemy 10 minut pod Wawel do wylotu ulicy Grodzkiej. Na skrzyżowaniu ulicy Grodzkiej i św. Idziego napotykamy pierwszy na trasie przykład wykorzystania wapieni jurajskich $\mathrm{w}$ architekturze miasta (Fig. 2, pkt. 5). Wokół kościoła św. Idziego zachowały się fragmenty dawnego bruku ulicznego, tak zwanych „kocich łbów”. Nawierzchnie te były układane z nieregularnych brył o średnicach od kilku do kilkudziesięciu centymetrów. Ich obłe kształty były efektem wielokrotnego przekładania oraz wieloletniego używania (Rajchel, 2009). Pozwalają nam one wyobrazić sobie jak wyglądały ulice dawnego Krakowa wykładane brukiem wapiennym (Fig. 6).

Po przejściu około 500 metrów wzdłuż ulicy Grodzkiej, skręcamy w lewo, w ulicę Franciszkańską, przy której znajduje się kościół oo. Franciszkanów (Fig. 2, pkt. 6). Jest jednym z pierwszych kościołów w Polsce zbudowanych z cegły. Jednak wspaniałe przypory tego kościoła zbudowane są z bloków skalnych wapienia jurajskiego tzw. grand appareil. Na terenie miasta możemy zaobserwować liczne przypory (skarpy) wykonane z tego surowca. Takim doskonałym przykładem jest skarpa budynku Auli św. Jakuba w bezpośrednim sąsiedztwie głównego wejścia do kościoła oo. Franciszkanów (Fig. 7). Innym pięknym przykładem jest skarpa budynku Collegium Maius (Fig. 8.), na rogu ulic Jagiellońskiej i św. Anny (Rajchel, 2004), która jest kolejnym punktem na naszej trasie (Fig. 2, pkt. 7). Dochodzimy tam idąc około 120 metrów wzdłuż Plant. Na uwagę zasługuje także fragment elewacji tego obiektu wykonany z nieobrobionych brył wapiennych tzw. opus incertum (Fig. 8), widocznych w ścianie od strony ulicy Jagiellońskiej. W wapiennych elementach elewacji możemy znaleźć liczne skamieniałości, na przykład amonity (Fig. 9). Będąc w tym miejscu, warto zwiedzić gmach Collegium Maius, który od 1400 roku jest siedzibą uniwersytetu i mieszczącego się tam Muzeum Uniwersytetu Jagiellońskiego. Jest to zatem najstarszy obiekt uniwersytecki w Polsce. Na dziedzińcu Collegium Maius możemy podziwiać kolumny wykonane $\mathrm{z}$ górnojurajskiego wapienia 
uławiconego. Wyraźnie zaznaczają się w nich krzemienie, których wielkość dochodzi do $15 \mathrm{~cm}$ (Fig. 10).

Kontynuując spacer proponowaną trasą, dochodzimy do kolegiaty św. Anny na ulicy o tej samej nazwie (Fig. 2, pkt. 8). Budowla wzniesiona na planie krzyża zaliczana jest do najpiękniejszych świątyń barokowych w Polsce. Obecny kościół jest już trzecią budowlą stojącą w tym samym miejscu, a kamień węgielny pod budowę dzisiejszej kolegiaty św. Anny został położony w 1689 roku (Rożek, 1993). Na uwagę zasługuje znajdująca się we wnętrzu kościoła kaplica św. Jana Kantego, w której znajdują się wysokie, 7,5-metrowe kolumny (Fig. 11) wykonane z tzw. „marmuru bł. Salomei”. „Marmurem” tym jest górnojurajski biohermalny wapień gąbkowy, należący do facji wapieni skalistych, wydobywany niegdyś w okolicy Ojcowa (Holcer, Krajewski, 2001).

Wapienny materiał skalny w postaci nieobrobionych brył skalnych był chętnie wykorzystywany przy budowie fortyfikacji. Spektakularnym przykładem jest Brama Floriańska (Fig. 2, pkt. 9) oraz baszty Ciesielska i Pasamoników, należące do pozostałości murów obronnych Krakowa (Rajchel, 2004). Aby dojść do Bramy Floriańskiej, kierujemy się Plantami wzdłuż ulicy Juliana Dunajewskiego i Basztowej. Pierwsze wzmianki na temat Bramy Floriańskiej pochodzą z 1307 roku. Wtedy wzniesiono zapewne kamienny cokół i ściany budowli, natomiast nakrywający ją obecnie hełm nałożono dopiero w 1694 roku, po zniszczeniu poprzedniego w czasie najazdu szwedzkiego. Brama liczy około 34 metrów wysokości (Michalec, 2005). Jej ściany tworzą łamane i nieobrobione bloki wapieni górnojurajskich.

\section{Istota stworzenia trasy geoturystycznej}

Miasto Kraków słynie z bogactwa zabytków architektonicznych różnych stylów. Posiada bogatą przeszłość historyczna. Proponowana trasa geoturystyczna ukazuje to miasto $\mathrm{z}$ innej perspektywy. Zwraca uwagę na pochodzenie wapienia górnojurajskiego, jednego z materiałów skalnych, charakterystycznych dla architektury Krakowa, przez wskazanie na terenie miasta miejsc eksploatacji wapieni górnej jury. Trasa jest również propozycją zapoznania się częściowo z geologiczną budową Krakowa.

Celem zbadania wiadomości odnośnie do miejsc występowania i architektonicznego wykorzystania wapieni górnojurajskich na terenie Krakowa, został przeprowadzony wywiad w postaci ankiety na grupie 100 przypadkowych respondentów w różnym wieku. Odpowiedzi zostały przeanalizowane pod względem wykształcenia w trzech grupach wiekowych: 18-30 lat, 31-55 lat, powyżej 56 lat.

Ankieta zawierała następujące pytania:

- „, Czy Pana/Pani zdaniem na terenie Krakowa występują kamieniołomy?"

- , Jeśli na powyższe pytanie udzielił Pan/Pani odpowiedzi pozytywnej, proszę o podanie ich nazw lub lokalizacji."

- „Czy orientuje się Pan/Pani, jaki materiał skalny był często wykorzystywany w budowlach Krakowa?"

- „Jeśli na powyższe pytanie udzielił Pan/Pani odpowiedzi pozytywnej, proszę o wymienienie go z nazwy."

Pytania wykazać miały także opinię ankietowanych na temat sensu utworzenia trasy geoturystycznej:
- „Czy Pana/Pani zdaniem utworzenie ścieżki geoturystycznej ukazującej miejsca naturalnych wystąpień surowca skalnego oraz wykorzystania ich w budownictwie Krakowa byłoby pozytywnym aspektem rozszerzenia oferty turystycznej miasta?".

Jak wynika z analizy odpowiedzi ankietowych, 58\% respondentów zdaje sobie sprawę $\mathrm{z}$ występowania na terenie Krakowa kamieniołomów, a w poszczególnych grupach wiekowych odpowiednio: 44\%, 69\% i 78\%. W grupie ludzi między 18-30 rokiem życia, znajomość tego tematu jest najmniejsza. Zdecydowanie większym problemem okazała się próba wskazania przez ankietowanych nazw lub lokalizacji istniejących kamieniołomów. Pięćdziesiąt cztery procent osób nie potrafiło wskazać ani jednego wyrobiska, w tym $64 \%$ w grupie między $18-30$ r. ż., $53 \%$ w grupie między 31-55 r. ż. i tylko 28\% w grupie osób powyżej 56 r. ż. Jedną nazwę kamieniołomu potrafiło podać $31 \%$ respondentów, a tylko $9 \%$ ankietowanych potrafiło wymienić dwie nazwy kamieniołomów. Najlepszą znajomością krakowskich kamieniołomów wykazały się osoby powyżej 56 roku życia (50\% podało jedną nazwę, $17 \%$ podało dwie nazwy). W grupie najmłodszych respondentów tylko 4\% osób potrafiło wymienić więcej niż dwie nazwy kamieniołomów występujących na terenie Krakowa.

Podjęto również próbę określenia wiedzy respondentów na temat materiału skalnego wykorzystywanego w architekturze Krakowa. Pięćdziesiąt procent ankietowanych orientuje się, jaki surowiec skalny był wykorzystywany w budowlach miasta, z czego $62 \%$ w grupie od $31-55$ r. ż. i $72 \%$ w grupie osób powyżej 56 r. ż. Natomiast w grupie osób młodych (18-30), aż 66\% nic nie wie na ten temat. Wśród skał wymienianych jako materiał wykorzystywany w elementach architektonicznych miasta Krakowa wskazywano: wapień (42\%), piaskowce i granit (13\%) oraz marmur (3\%). Jak wynika $z$ ankiety, wiedza na temat materiału skalnego wykorzystywanego w budowlach miasta oraz miejsc jego pochodzenia czy eksploatacji jest niezadowalająca. Może dlatego aż 90\% respondentów deklaruje potrzebę utworzenia trasy geoturystycznej, która mogłaby połączyć te dwa aspekty ze sobą. W poszczególnych grupach wiekowych odpowiednio za stworzeniem takiej trasy wypowiedziało się: $90 \%, 84 \%$ oraz $100 \%$. Uwzględniając poziom wykształcenia ankietowanych, największą znajomością obecności kamieniołomów w Krakowie wykazały się osoby z wykształceniem zawodowym (89\%), natomiast zdecydowanie mniejszą z podstawowym (67\%) i wyższym $(66 \%)$. Na temat surowców wykorzystywanych w architekturze najlepszą wiedzą wykazały się osoby z wykształceniem podstawowym (67\%) i zawodowym (56\%). Za utworzeniem trasy geoturystycznej opowiadają się osoby z wykształceniem podstawowym (100\%) i wyższym (94\%).

\section{Podsumowanie}

Turystyka dla przeciętnego turysty kojarzy się z obserwacją przyrody lub zwiedzaniem malowniczych krajobrazów i doznawaniu wrażeń estetycznych. Obecnie funkcja poznawcza w większości aglomeracji miejskich opiera się przede wszystkim na zwiedzaniu i poznawaniu historii zabytkowych budowli. Prawie zupełnie nie zwraca się uwagi 
na to, z czego poszczególne elementy architektoniczne są wykonane. Turyści, jak wynika z przeprowadzonego wywiadu, nie mają wiedzy na temat pochodzenia materiału skalnego, który został wykorzystany w budowlach. Jeszcze mniejszą wiedzę mają na temat miejsc eksploatacji tych surowców.
Brakuje takiej informacji w materiałach reklamowych i przewodnikach. Propozycja trasy geoturystycznej zwraca uwagę na ten problem i stwarza tym samym nową ofertę dla zainteresowanych turystów, podnosząc wiedzę o odwiedzanych i podziwianych obiektach architektonicznych.

\section{References (Literatura)}

Dżułyński, St., 1953. Tektonika południowej części Wyżyny Krakowskiej. Acta Geologia Polonica, 3.

Górecki, J., Sermet, E., 2010. Kamieniołomy Krakowa - dziedzictwo niedocenione. W: Zagożdżon, P., Madziarz, M., (eds), Dzieje górnictwaelement europejskiego dziedzictwa kultury, III: 123-138.

Gradziński, R., 1972. Przewodnik geologiczny po okolicach Krakowa. Wydawnictwa Geologiczne, Warszawa.

Holcer, Z., Krajewski, M., 2001. Wykorzystanie górnojurajskich wapieni biohermalnych jako materiału zdobniczego w XVII-wiecznym budownictwie sakralnym. Geologia, 27: 257-266.

Krajewski, M., 2001. Wykształcenie litologiczne i warunki sedymentacji osadów oksfordu i kimerydu zrębu Zakrzówka w Krakowie. Przewodnik LXXII Zjazdu Polskiego Towarzystwa Geologicznego, Kraków: 37-49.

Matyszkiewicz, J., 1993. Stromatactis w jurajskich budowlach węglanowych okolic Krakowa. Przeglad Geologiczny, 41: 248-252.

Matyszkiewicz, J., 2001. Rola obszaru krakowskiego w sedymentacji osadów górnej jury Wyżyny Krakowsko-Częstochowskiej. Przegląd Geologiczny, 49: 724-727.

Michalec, B., 2005. Przewodnik kieszonkowy - Kraków. Pascal, Bielsko-Biała.

Rajchel, J., 1970. Badania sedymentologiczne krzemieni jurajskich pod Krakowem. Spraw. z Pos. Kom. PAN, Oddz. W Krakowie, XIV/2: 625-629.
Rajchel, J., 2004. Kamienny Kraków, Spojrzenie geologa. AGH Uczelniane Wydawnictwa Naukowo-Dydaktyczne, Kraków.

Rajchel, J., 2008. Geologiczne spojrzenie na architekturę Krakowa. W: Haczewski, G., (ed.), Pierwszy Kongres Geologiczny: przewodnik sesji terenowych, Kraków: 5-13.

Rajchel, J., 2009. Tradycyjne bruki w krajobrazie Krakowa. Geologia, 35 : 41-55.

Rożek, M., 1993. Przewodnik po zabytkach i kulturze Krakowa. PWN, Warszawa.

Szczepańska, M., 2005. Przegląd wyrobisk górniczych Krzemionek Podgórskich. W: Szczepańska, M., Pilecka, E. (eds), Geologiczno-przyrodnicze rozpoznanie terenów pogórnicznych Krzemionek podgórskich dla potrzeb ochrony ich wartości naukowo-dydaktycznych i ekologicznych, Wyd. Instytutu Gospodarki Surowcami Mineralnymi i Energią PAN, Kraków: 43-59.

Świerczewska, A., 1989. Krzemienie z wapieni górnego Oksfordu okolic Ujazdu. W: Rutkowski, J. (ed), Przewodnik LX Zjazdu Polskiego Towarzystwa Geologicznego w Krakowie, Warszawa: 88-90.

Żółciak, K., Żółciak, J., 2007. Park im. Wojciecha Bednarskiego. Wyd. Ośrodek Kultury im. Cypriana Kamila Norwida. 